UDC $539.3 ; 537.39$

\title{
Experimental Evaluation of Pulse Electric Current Effect on Residual Stresses in Composite-to-Copper Joints
}

\author{
G. V. Stepanov, ${ }^{a}$ A. I. Babutskii, ${ }^{a}$ I. A. Mameev, ${ }^{\text {a }}$ M. Ferraris, ${ }^{b}$ V. Casalegno, ${ }^{\text {b }}$ \\ and M. Salvo ${ }^{b}$ \\ ${ }^{\text {a }}$ Pisarenko Institute of Problems of Strength, National Academy of Sciences of Ukraine, \\ Kiev, Ukraine \\ ${ }^{\mathrm{b}}$ Materials Science and Chemical Engineering Department, Politecnico di Torino, Torino, \\ Italy
}

удК $539.3 ; 537.39$

\section{Экспериментальная оценка влияния импульсного электрического тока на остаточные напряжения в соединении композит-медь}

\section{Г. В. Степанов", А. И. Бабуцкий ${ }^{a}$, И. А. Мамеев ${ }^{a}$, М. Феррарис B. Касалегно ${ }^{6}$, М. Салво}

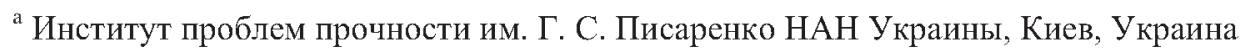

б Туринский политехнический институт, Турин, Италия

Представлена эксперилентальная методика оченки распределения остаточньх напряжений в соединении композита (углерод, упрочненный углеродными волокнами) с медью. Установлено, что иипульс электрического тока, пропущенный через соединение композит-медь, суиественно снижает уровень остаточных напряжений.
}

Ключевые слова: соединение композит-медь, остаточные напряжения, импульсный электрический ток.

Introduction. The effect of residual stresses (RS) on strength, or more particularly on thermal or mechanical fatigue, of structural elements has been object of numerous studies. Although a great variety of techniques for RS reduction is available, their optimization and development of new ones is an ongoing process. In accordance with numerous experimental data, pulse electric current (PEC) has a considerable effect on stress relaxation in metals under active loading (elongation) [1-3], while information on RS relaxation under PEC conditions is scarce. It is known that treatment based on application of PEC causes reduction of type 1 and type 2 residual stresses after metal-forming technological operations [4], and some data on pulse electro-magnetic treatment for welding RS reduction are available [5]. As to the authors' knowledge, there are no publications covering the PEC effect on RS in composite-to-metal joints.

We present the results of experimental determination of $\mathrm{RS}$ in carbon fiber-reinforced carbon composite (CFC) joined to copper, before and after pulse electric current treatment (PECT).

(C) G. V. STEPANOV, A. I. BABUTSKII, I. A. MAMEEV, M. FERRARIS, V. CASAlEGNO, M. SAlvo, 2008

ISSN 0556-171X. Проблемы прочности, 2008, № 4 
Technique to Join Composite to Copper. CFC has excellent thermomechanical properties, such as high thermal conductivity, good thermal shock and thermal fatigue resistance. Due to these characteristics, the CFC is intended to be applied in the ITER (International Thermonuclear Experimental Reactor) as plasma facing components, which interact directly with the plasma [6]. This work deals with the realization of a high heat flux component formed by an armour (CFC) and a heat-sink material (copper alloy, $\mathrm{CuCrZr}$ grade), which transfers the heat from the armour to the water flowing in the cooling channel of the heat sink. One of the most critical steps in this component manufacturing is the joint between $\mathrm{CFC}$ and the copper alloy $(\mathrm{CuCrZr})$ : the joints must withstand cyclic thermal-mechanical loads and neutron radiation to provide an acceptable design lifetime and reliability. In particular, the divertor must sustain 3000 cycles at $10 \mathrm{MW} / \mathrm{m}^{2}$ plus 300 cycles at $20 \mathrm{MW} / \mathrm{m}^{2}$.

The main problem related to the $\mathrm{CFC}-\mathrm{Cu}$ alloy joints is the large thermal expansion mismatch between the two materials, which generates large RS at the interface during the joining process. These RS can be partially relaxed by the introduction of a very ductile layer of pure copper between the CFC composite and the $\mathrm{Cu}$ alloy. $\mathrm{CFC} / \mathrm{Cu}$ joint can nott be obtained by direct casting of copper on $\mathrm{CFC}$ surface, due to zero wettability of $\mathrm{CFC}$ for $\mathrm{Cu}$; in fact, the contact angle of molten copper on carbon substrate is about $140^{\circ}$; the $\mathrm{C}-\mathrm{Cu}$ system is a non-reactive system: $\mathrm{C}$ and $\mathrm{Cu}$ are not soluble in the solid state and they do not form stable carbides [7].

To improve the wettability of molten copper on CFC, the surface of the composite was modified by direct solid-state reaction at high temperature between a transition metal of VI B group and the CFC $[8,9]$. Different metals from the VI $\mathrm{B}$ group (including chromium) were deposited on the CFC surface. The next heat treatment led to the formation of a thin carbide layer $(15-20 \mu \mathrm{m})$ on the composite surface. The reaction between $\mathrm{CFC}$ and a transition metal leads to a composite surface modification: the new modified carbide-based surface is wetted by molten copper. The most desirable form of reaction product between the metal and the composite is a coherent and adherent carbide layer, which can be wetted by copper.

The direct joining of copper to $\mathrm{CFC}$ was performed in a special graphite sample holder, where the modified CFC and copper were placed and heated at $1100^{\circ} \mathrm{C}$ for $1 \mathrm{~h}, \mathrm{Ar}$ flow. The wetting experiments were performed at $1100^{\circ} \mathrm{C}$ for $30 \mathrm{~min}$, but the contact angle of molten copper on the substrate did not change after the first two minutes. Optical micrograph (Fig. 1) shows continuous interfaces between $\mathrm{Cr}$ carbide and copper and between $\mathrm{Cr}$ carbide and $\mathrm{CFC}$ : a dense carbide layer (about $10 \mu \mathrm{m}$ ) and a less compact carbide layer (about $10 \mu \mathrm{m}$ ) are clearly observable. The last one is completely infiltrated by copper; in that sense, the wettability of molten copper on CFC substrate is enhanced by the $\mathrm{Cr}$ carbide layer.

In spite of the large thermal expansion mismatch between CFC and copper, no cracks are revealed in the composites or at the interface after cooling from copper melting temperature to room temperature, and no limitations are placed to the thickness of the copper layer casting on CFC (up to $5 \mathrm{~mm}$ have been successfully cast). 


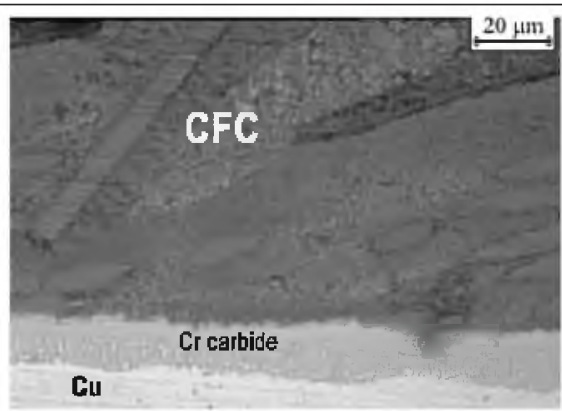

Fig. 1. Optical micrograph of CFC-to-Cu transition zone.

The results of CFC-to-Cu joint development showed that the chromium modification was the best solution to have a good wettability and a strong interface. Some of these samples $(19 \times 22 \times 8 \mathrm{~mm})$ were successfully brazed to the $\mathrm{CuCrZr}$ alloy. The brazing process includes a rapid cooling from 975 (brazing temperature) to $450^{\circ} \mathrm{C}\left(>1{ }^{\circ} \mathrm{C} / \mathrm{s}\right)$ and an isothermal treatment at $450^{\circ} \mathrm{C}$ for $3 \mathrm{~h}$ in vacuum. The brazing process is particularly severe for $\mathrm{CFC} /$ pure $\mathrm{Cu}$ joints; the $\mathrm{CFC} / \mathrm{Cu}$ joint is submitted to a severe thermal shock due to cooling rate. In fact, cooling from the braze cycle temperature produces high residual stresses that can promote subsequent cracking during service.

As mentioned above, the intermediate ductile layer of pure copper between $\mathrm{CFC}$ and $\mathrm{CuCrZr}$ alloy is introduced to minimize thermal expansion mismatch $\left(\alpha_{\mathrm{CFC}}=2.5 \cdot 10^{-6}{ }^{\circ} \mathrm{C}^{-1}, \quad \alpha_{\mathrm{CuCrZr}}=(16-17) \cdot 10^{-6}{ }^{\circ} \mathrm{C}^{-1}\right)$. Nevertheless, the problem is not solved completely because the thermal expansion coefficient for pure copper is the same as for $\mathrm{CuCrZr}$ alloy $\left(\alpha_{\mathrm{Cu}}=16.6 \cdot 10^{-6}{ }^{\circ} \mathrm{C}^{-1}\right)$, and reasons for $\mathrm{RS}$ formation in $\mathrm{CFC}$-to- $\mathrm{Cu}$ joint remain. To investigate $\mathrm{RS}$ in the composite jointed to copper and determine PECT influence on change of RS, specimens with dimensions $9 \times 9 \times 30 \mathrm{~mm}$ were manufactured (pure $\mathrm{Cu}$-layer was $3 \times 9 \times 30 \mathrm{~mm}$ ).

Basics of Experimental-Calculation Procedure for RS Evaluation. Destructive (slotting) method for determination of RS distribution was chosen at the fulfillment of this investigation. According to the method, controlled step-bystep removal or slotting of the material from the one side and registration of corresponding elastic deformations on the opposite side is used. The RS existing in the removed material then can be calculated from the measured deformations (strains). This is the fundamental basis for the destructive measurement methods [10]. The measured deformation at a given point in the material depends on all the stresses within the removed material. The simplest way to determine such relation is a modeling using finite element method (FEM). In our case, RS distribution in CFC-layer can be determined by step-by-step slotting of CFC and congruous measuring of the strains on the opposite side (on free surface of $\mathrm{Cu}$-layer).

Experimental-calculation procedure for RS estimation is based on the superposition principle: slot execution on every $m$ th slotting section $(m=1, \ldots, n$, where $n$ is a number of sections of the whole slot) of CFC-layer causes a drop to zero of stresses, which are ortogonal to the slotting plane and corresponding change of strain $\delta \varepsilon_{m}$ on the opposite side (copper free surface) of the specimen 
which is proportional to averaged stress $\sigma_{m}$ existing in this $m$ th section before slotting $\left(\delta \varepsilon_{m}=k_{m} \sigma_{m}\right)$. The same will be observed on each step (slotting section), moreover, $\sigma_{m}$ stress will be a sum of an initial residual stress $\sigma_{R, m}$ on this section and its total change due to the fulfillment of previous slotting steps $\left(\sigma_{m}=\sigma_{R, m}+k_{m, 1} \sigma_{R, 1}+\ldots+k_{m, m-1} \sigma_{R, m-1}\right)$.

Thus, under execution of each subsequent slotting step, the corresponding strains can be calculated in the following sequence

$$
\begin{aligned}
& \delta \varepsilon_{1}=k_{1} \sigma_{R, 1}, \\
& \delta \varepsilon_{2}=k_{2}\left(\sigma_{R, 2}+k_{1,2} \sigma_{R, 1}\right) \text {, } \\
& \delta \varepsilon_{3}=k_{3}\left(\sigma_{R, 3}+k_{1,3} \sigma_{R, 1}+k_{2,3} \sigma_{R 2}\right) \text {, } \\
& \delta \varepsilon_{n}=k_{n}\left(\sigma_{R, n}+k_{1, n} \sigma_{R, 1}+k_{2, n} \sigma_{R, 3}+\ldots+k_{n-1, n} \sigma_{R, n}\right) .
\end{aligned}
$$

After factors $k_{1}, \ldots, k_{n}$ and $k_{1,2}, \ldots, k_{n-1, n}$ are known (e.g., from results of FEM modeling), it will be possible by taking into account the registered strain increment $\delta \varepsilon_{m}$ on each consecutive slotting step to determine the initial residual stresses $\sigma_{R, m}$ for these steps using the following equations obtained from (1):

$$
\begin{aligned}
& \sigma_{R, 1}=\delta \varepsilon_{1} / k_{1} \\
& \sigma_{R, 2}=\delta \varepsilon_{2} / k_{2}-k_{1,2} \sigma_{R, 1} \text {, } \\
& \sigma_{R, 3}=\delta \varepsilon_{3} / k_{3}-k_{1,3} \sigma_{R, 1}-k_{2,3} \sigma_{R, 2} \text {, } \\
& \sigma_{R, n}=\delta \varepsilon_{n} / k_{n}-k_{1, n} \sigma_{R, 1}-k_{2, n} \sigma_{R, 2}-\ldots-k_{n-1, n} \sigma_{R, n}
\end{aligned}
$$

Factors $k_{1}, \ldots, k_{n}$ and $k_{1,2}, \ldots, k_{n-1, n}$ do not depend on the residual stress distribution specifics and depend only on the elastic properties of layers, their strain hardening, geometry of the investigated specimen, step slotting increase in depth and its width. Noteworthy is that, in case of inelastic behavior of a material under cutting, the above factors account for the plastic deformation effect. This allows one to use the technique under possible nonlinear deformation of $\mathrm{CFC}$ layer under slotting.

The initial modeling of RS formation processes at cooling from copper melting temperature to the room temperature was performed using the ANSYS-ED package. Then stress-strain-state changes under slotting of CFC-layer were modeled.

Calculations were carried out assuming that mechanical and thermo-physical properties of the CFC and copper (assigned by specimen manufacturer) change linearly depending on temperature according to data mentioned in the Table 1. At the first stage (cooling) of the stress-strain-state of the sample in length of $30 \mathrm{~mm}$ was calculated at plane deformation condition for zero initial stresses. Two-part material was considered: $\mathrm{CFC}$-layer with the thickness of $6 \mathrm{~mm}$ and copper-layer with the thickness of $3 \mathrm{~mm}$. It was specified that the initial temperature of the 
materials was $1000^{\circ} \mathrm{C}$. Then the problem of cooling under convection heat exchange with an environment through an external layer of copper (other surfaces were thermally insulated) was numerically solved. Heat exchange was characterized by convection factor $k=20 \mathrm{~W} /\left(\mathrm{m}^{2} \cdot{ }^{\circ} \mathrm{C}\right)$. Cooling time of the specimen used in calculations was about $1000 \mathrm{~s}$.

$\mathrm{T}$ a $\mathrm{b} 1 \mathrm{e} 1$

Temperature Dependences of Mechanical and Thermo-Physical Properties

\begin{tabular}{|c|c|c|c|c|c|c|c|c|}
\hline$T,{ }^{\circ} \mathrm{C}$ & $\begin{array}{c}\text { Yield } \\
\text { stress } \\
\sigma_{Y}, \mathrm{MPa}\end{array}$ & $\begin{array}{c}\text { Tangent } \\
\text { modulus } \\
M, \mathrm{MPa}\end{array}$ & $\begin{array}{c}\text { Young's } \\
\text { modulus } \\
E, \mathrm{MPa}\end{array}$ & $\begin{array}{c}\text { Poisson's } \\
\text { ratio } \\
v\end{array}$ & $\begin{array}{c}\text { Density } \\
\rho, \\
\mathrm{kg} / \mathrm{m}^{3}\end{array}$ & $\begin{array}{c}\text { Thermal } \\
\text { expansion } \\
\alpha,{ }^{\circ} \mathrm{C}^{-1}\end{array}$ & $\begin{array}{c}\text { Specific } \\
\text { heat } \\
C_{p}, \\
\mathrm{~J} /(\mathrm{kg} \cdot \mathrm{K})\end{array}$ & $\begin{array}{c}\text { Thermal } \\
\text { conductivity } \\
\eta, \\
\mathrm{W} /(\mathrm{m} \cdot \mathrm{K})\end{array}$ \\
\hline 0 & 75.0 & 3900 & $1.25 \cdot 10^{5}$ & 0.35 & 8900 & $166 \cdot 10^{-5}$ & 400 & 400 \\
\hline 1000 & 7.7 & 355 & $0.57 \cdot 10^{5}$ & 0.49 & 8755 & $2.50 \cdot 10^{-5}$ & 400 & 400 \\
\hline 0 & 100.0 & 100 & $1.00 \cdot 10^{5}$ & 0.10 & 1923 & $2.50 \cdot 10^{-6}$ & 780 & 330 \\
\hline 1000 & 36.0 & 36 & $0.55 \cdot 10^{5}$ & 0.10 & 1910 & $2.50 \cdot 10^{-6}$ & 1700 & 153 \\
\hline
\end{tabular}

* Properties for CFC were averaged by the CFC volume.

Data about RS distribution in the CFC-layer are presented in Fig. 4, curve 1 (directions of $x$ and $y$ axes are the same as in Fig. 2). In the Cu-layer, the maximum value of stresses are generated on the layers interface, $\sigma_{x}^{\max }=117 \mathrm{MPa}$; the minimum value of stresses was on the free copper surface, $\sigma_{x}^{\min }=87 \mathrm{MPa}$. The above stress distribution is a result of non-uniform elastic-plastic deformation of $\mathrm{Cu}$-layer during cooling.

The second part of the modeling was a simulation of step-by-step slotting of CFC-layer with increment of $1 \mathrm{~mm}$. Slotting was simulated by "eliminating" the finite elements in the CFC part of the FEM model. Calculated strains on free copper surface (corresponding to the strain gauge location) under slots modeling in the CFC are presented in Fig. 3: calculated strains (points 1 ) are in agreement with experimental ones (points 2). Using the obtained simulation results (stress distributions and respective data on strains for each slot depth), it is possible to determine factors $k_{1}, \ldots, k_{n}$ and $k_{1,2}, \ldots, k_{n-1, n}$. In our case, the values of averaged stresses $\sigma_{m}$, which existed in each slotting section before cutting, were taken from RS distribution diagram presented on Fig. 4, curve 1 (spots). Using strain registration data, mentioned factors of $k_{1}, \ldots, k_{n}$ and $k_{1,2}, \ldots, k_{n-1, n}$, as well as Eqs. (2), the real RS distributions in CFC-layer can be calculated.

PEC Effect on RS in the Joint. PEC effect on residual stresses in the joint was investigated by comparison of RS distribution in specimens before and after PEC treatment. The scheme of PECT is presented in Fig. 2. Treatment was performed using pulse electric current generator consisting of high voltage power supply, capacitor banks and discharge switch [11]. Registration of the pulse electric current parameters was realized using the Rogovsky coil, high-frequency 
$\mathrm{A} / \mathrm{D}$ converter and $\mathrm{PC}$ where data were stored and processed. Treatment was carried out by direct current passage through the joined $\mathrm{CFC}$-to-Cu sample. Two short sequential pulses of the electric current with maximum amplitude of $I_{\max } \approx 87 \mathrm{kA}$ were passed through the sample (through $9 \times 9 \mathrm{~mm}$ cross section). Average temperature increase of the sample as a result of the treatment did not exceed $10^{\circ} \mathrm{C}$.
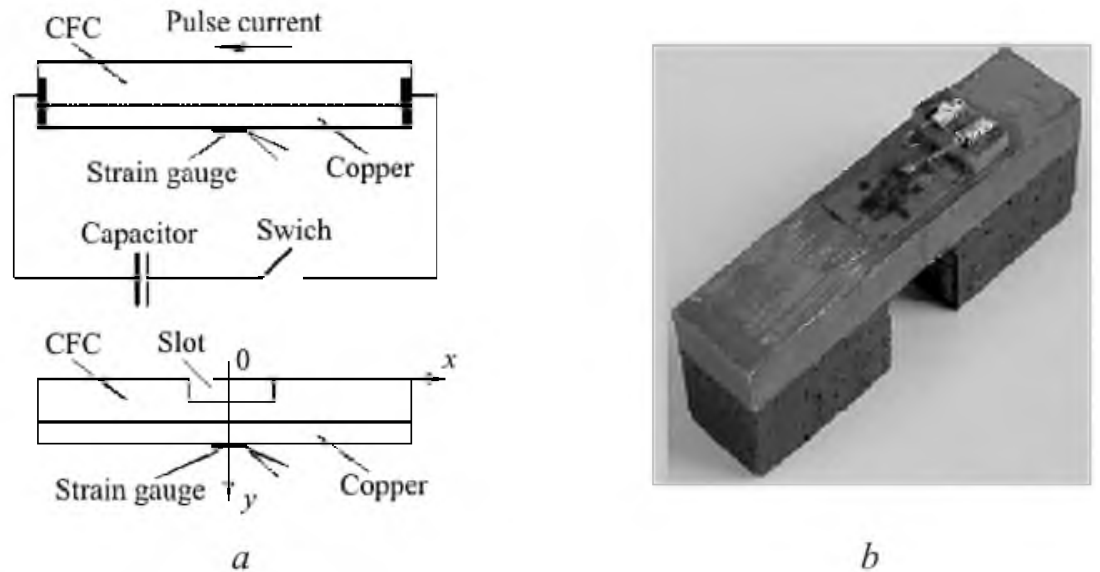

Fig. 2. Schemes of IECT, strain registration, and slotting $(a)$; specimen after testing $(b)$

Before tests one 5-mm strain gauge was glued to the $\mathrm{Cu}$-layer of the specimen in the middle part (see Fig. 2). Data on the gauge strains and their variation under slotting (slot width $B=6 \mathrm{~mm}$ ) were obtained using the commercial ICP CON I-7016P module. Using ICP CON I-7520 (RS 232) module the above data were fed to PC.

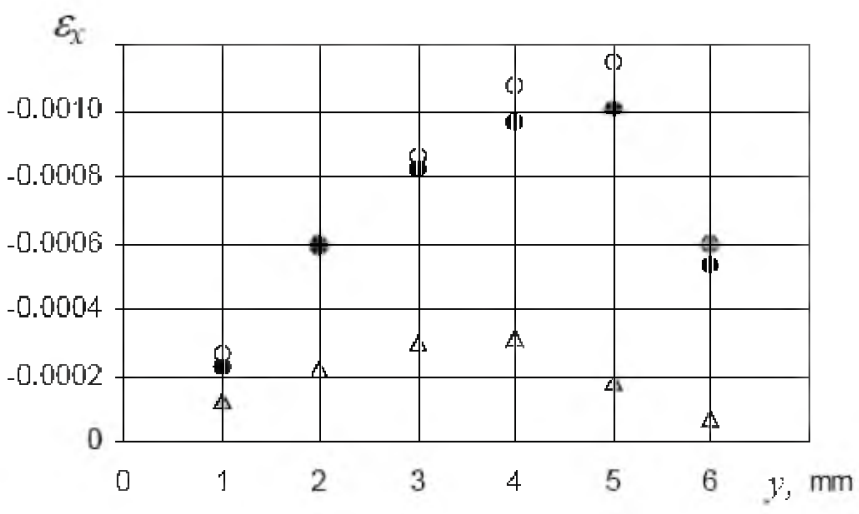

Fig. 3. Variation of deformations $\varepsilon_{x}$ under step-by-step slotting of CFC-layer: before PECT $[(O)$

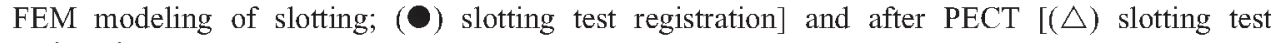
registration].

PEC treatment of specimens caused changes of stress distribution, which were registered via variation in strain distribution during the slotting. This effect is illustrated by Fig. 3. Residual stress distributions obtained from strain registration data before and after PECT are presented in Fig. 4 (curves 2 and 3). Our tests indicate an essential decrease of residual stresses after PECT. 


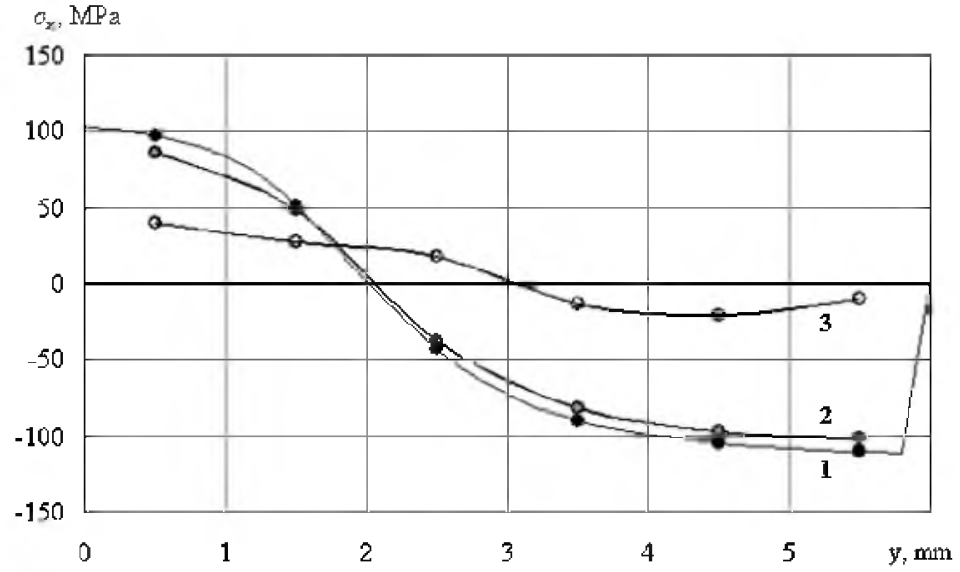

Fig. 4. Residual stress $\left(\sigma_{x}\right)$ distribution diagram through the thickness of CFC-layer obtained by FEM modeling of cooling process ( 1 ) and from tests: before (2) and after (3) PECT.

Conclusions. The results of our investigations show that pulse electric current treatment of CFC-to-copper joint causes significant decrease of residual stresses. This effect cannot be attributed to the Joule heating.

Microstructural changes in CFC-to-copper joint after the treatment are the object of our further investigations.

This work was supported in part by the EU Network of Excellence project Knowledge-based Multicomponent Materials for Durable and Safe Performance (KMM-NoE) under the contract No. NMP3-CT-2004-502243.

\section{Резиме}

Представлено експериментальну методику щодо оцінки розподілу залишкових напружень у з'єднанні композита (вуглець, зміцнений вуглецевими волокнами) з міддю. Установлено, що імпульс електричного струму, що пропушений через з'єднання композит-мідь, суттєво зменшує рівень залишкових напружень.

1. Yu. V. Baranov, O. V. Troitskii, Yu. S. Avraamov, and A. D. Shlyapin, Physical Grounds of Electric Pulse and Electric Current/Plasic Treatments and New Materials [in Russian], MGIU, Moscow (2001).

2. A. F. Sprecher, S. L. Mannan, and H. Conrad, "On the mechanisms for the electroplastic effects in metals," Acta Metal., 34, No. 7, 1145-1162 (1986).

3. G. V. Stepanov, A. I. Babutskii, I. A. Mameev, and A. N. Olisov, "Analysis of pulse current-induced tensile stress relaxation," Strength Mater., 38, No. 1, 84-91 (2006).

4. V. A. Boguslaev, A. I. Dolmatov, P. D. Zhemanyuk, et al., Life Prolongation of Gas Turbine Disk Titanium Alloy Parts [in Russian], Zaporozhye (2000).

5. A. D. Glinberg, N. A. Karandashev, A. F. Krutin, and E. N. Sidorenkov, "Practics and perspectives of application of magnetic-pulse treatment of metals," in: Proc. Int. Conf. on Action of Electromagnetic Fields and Electric Current on Metals (October 21-24, 2003), Moscow (2003), pp. 55-57. 
6. M. Merola, M. Akiba, V. Barabash, and I. Mazul, "Overview on fabrication and joining of plasma facing and high heat flux materials for ITER," $J$. Nucl. Mater., 307-311, 1524-1532 (2002).

7. N. Eustathopoulos, M. G. Nicholas, and B. Drevet, Wettability at High Temperature, Pergamon Press (1999).

8. P. Appendino, M. Ferraris, V. Casalegno, et. al., "Direct joining of CFC to copper," J. Nucl. Mater., 329-333, 1563-1566 (2004).

9. P. Appendino, M. Ferraris, V. Casalegno, et al., "Proposal for a new technique to join CFC composites to copper," Ibid., 348, No. 1-2, 102-107 (2006).

10. G. S. Schajer and M. B. Prime, "Use of inverse solutions for residual stress measurement," J. Eng. Mater. Technol., 128, No. 3, 375-382 (2006).

11. G. V. Stepanov, A. I. Babutskii, and I. A. Mameev, "High-density pulse current-induced unsteady stress-strain state in a long rod," Strength Mater., 36, No. 4, 377-381 (2004).

Received 11.07. 2007 